\title{
A velvet worm (Onychophora: Peripatidae) feeding on a free ranging spider in Sierra Llorona, Panama
}

\author{
Macario González ${ }^{1}$, Ángel Sosa-Bartuano² \& Julián Monge-Nájera ${ }^{3}$ \\ 1. Escuela de Biología, Facultad de Ciencias Naturales y Exactas, Universidad Autónoma de Chiriquí, David, Panamá; macariogonzp@gmail.com \\ 2. Colección Zoológica Dr. Eustorgio Méndez, Departamento de Investigación en Entomología Médica, Instituto Conmemorativo Gorgas de \\ Estudios de la Salud, Ciudad de Panamá, Panamá; asosa2983@gmail.com \\ 3. Laboratorio de Ecología Urbana, Universidad Estatal a Distancia (UNED), 2050 San José, Costa Rica; julianmonge@gmail.com
}

Received 15-XI-2017 • Corrected 12-XII-2017 • Accepted 30-I-2018

ABSTRACT: Onychophoran worms seldom attack spiders because spiders are agile and dangerous prey. Here we report an onychophoran feeding on a spider (possibly a Ctenidae) in Sierra Llorona, Colón, Panamá $\left(9,35863^{\circ}-79,70287^{\circ}\right.$; altitude $\left.491 \mathrm{~m}\right)$.

Key words: Neotropical invertebrates, adhesive net, private reserve, tropical rainforest.
RESUMEN: Gusano de terciopelo (Onychophora: Peripatidae) alimentándose de una araña en Sierra Llorona, Panamá. Los gusanos de terciopelo rara vez atacan a las arañas porque éstas son presas ágiles y peligrosas. Aquí informamos de un onicóforo comiendo una araña (posiblemente de la familia Ctenidae) en Sierra Llorona, Colón, Panamá $\left(9,35863^{\circ}-79,70287^{\circ} ; 491 \mathrm{msnm}\right)$.

Palabras clave: invertebrados neotropicales, red adhesiva, reserva privada, selva tropical.
Onychophoran worms are ancient predators that can only live in moist microhabitats and hunt for small invertebrates at night (mostly insects, myriapods, spiders and crustaceans, Read \& Hughes, 1987; Monge-Nájera, Barrientos \& Aguilar, 1993). However, many spiders are agile and dangerous to onychophorans, and probably they are not frequent prey (Read \& Hughes, 1987; Dias \& Lo-Man-Hung, 2009); furthermore, some spiders can kill and eat onychophorans (Franco \& Monge-Nájera, 2016). Here we report an onychophoran feeding on a spider in Panama.

The observation was made on July 18, 2017, at 10:21 pm, in Sierra Llorona Private Reserve, Colón, Panama; 9,35863- $79,70287^{\circ} ; 491$ masl; Premontane Very Moist Forest; precipitation: 3000 a $3500 \mathrm{~mm}$ (Autoridad Nacional del Ambiente de Panamá, 2010).

On a mossy rock at the edge of a creek, the first author found an onychophoran feeding on a spider, which was still moving its legs slowly (Figure 1). That same night he saw four more onychophorans in understory vegetation, but none were feeding. The worm was about $7 \mathrm{~cm}$ long and the spider about $4 \mathrm{~cm}$ long. For future reference, we propose the common name of "Sierra Llorona LeatherBrown Collared Onychophoran" for this species (SosaBartuano, Monge-Nájera \& Morera-Brenes, 2018).

The spider seemed to be a ctenid; the family Ctenidae has at least 16 species in Panama (Quintero, 2005). They do not build webs and include aggressive and poisonous species that hunt at night among soil vegetation. These are dangerous spiders and perhaps the onychophoran found a weakened individual and secured it with adhesive, but it is also possible that the worm killed a healthy spider thanks to its stealth hunting behavior (MoreraBrenes \& Monge-Nájera, 2010).

We thank Diomedes Quintero and William Eberhard for information on the behavior and possible identity of the spider. 

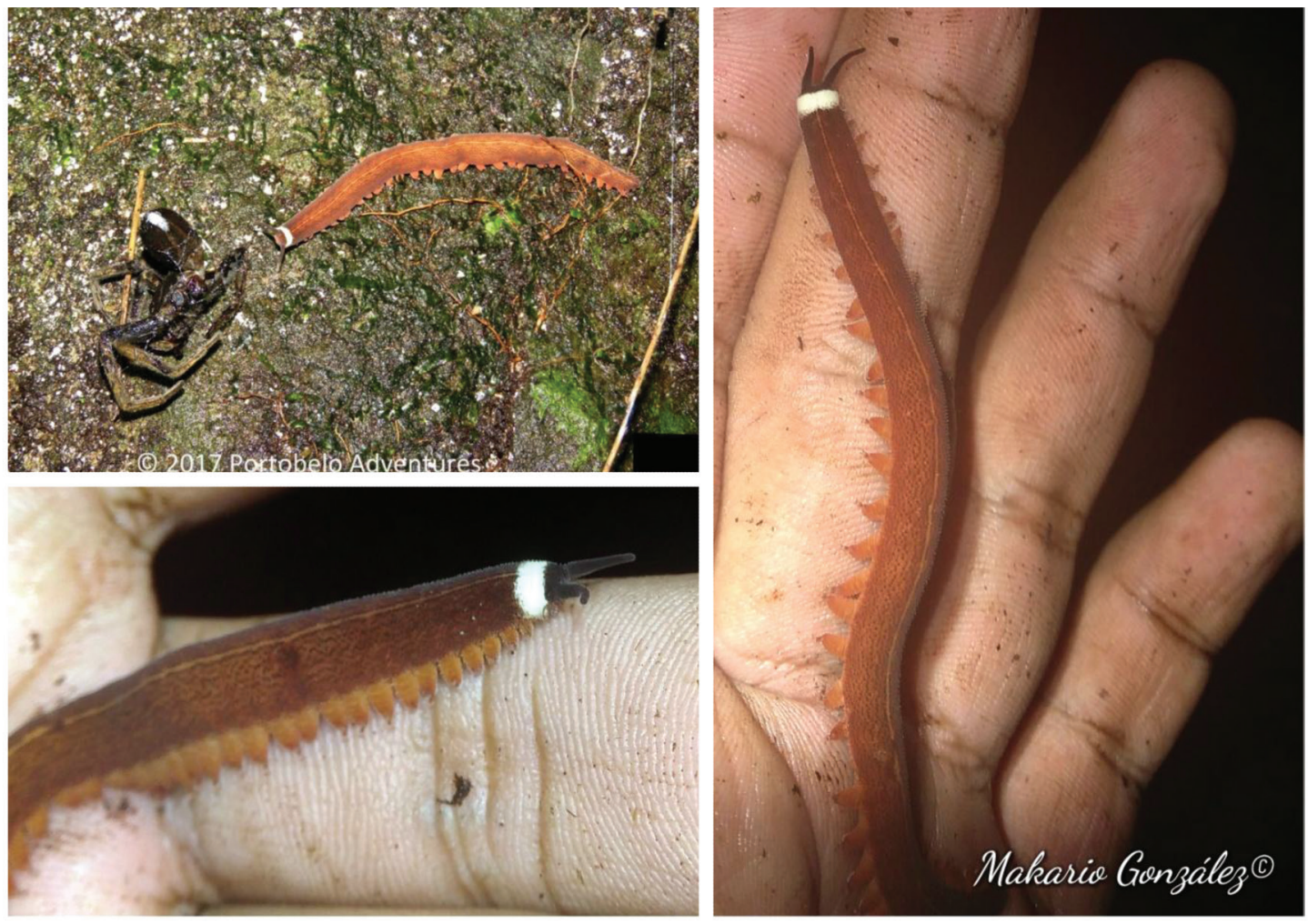

Fig. 1. Onychophoran found feeding on a spider in Sierra Llorona, Colón, Panamá (July, 2017). Photographs by Jesse Ashcroft and M. González.

\section{REFERENCES}

Autoridad Nacional del Ambiente de Panamá. (2010). Atlas Ambiental de la República de Panamá. Panama: Gobierno de Panamá.

Dias, S. C., \& Lo-Man-Hung, N. F. (2009). First record of an onychophoran (Onychophora, Peripatidae) feeding on a theraphosid spider (Araneae, Theraphosidae). Journal of Arachnology, 37(1), 116-117. doi: 10.1636/ST08-20.1

Franco, R., \& Monge-Nájera, J. (2016). Inverted roles: Spider predation upon Neotropical velvet worms (Epiperipatus spp.; Onychophora: Peripatidae). UNED Research Journal, 8(2),171-173. doi: 10.22458/urj.v8i2.1557

Monge-Nájera, J., Barrientos, Z., \& Aguilar, F. (1993). Behavior of Epiperipatus biolleyi (Onychophora: Peripatidae) under laboratory conditions. Revista de Biología Tropical, 41(3 A), 689-696.
Morera-Brenes, B., \& Monge-Nájera, J. (2010). A new giant species of placented worm and the mechanism by which onychophorans weave their nets (Onychophora: Peripatidae). Revista de Biología Tropical, 58(4), 11271142. doi: $10.15517 /$ rbt.v58i4.5398

Quintero, D. (2005). Arácnidos. In: S. Castroviejo \& A. Ibáñez (eds.). Estudios sobre la biodiversidad de la región de Bahía Honda (Veraguas, Panamá). Madrid: Consejo Superior de Investigaciones Científicas.

Read, V. S. J., \& Hughes, R. N. (1987). Feeding behaviour and prey choice in Macroperipatus torquatus (Onychophora). Proceedings of the Royal Society of London B: Biological Sciences, 230(1261), 483-506. doi: 10.1098/ rspb.1987.0030

Sosa-Bartuano, Á., Monge-Nájera, J., \& Morera-Brenes, B. (2018). A proposed solution to the species problem in velvet worm conservation (Onychophora). UNED Research Journal, 10(1), 204-208. doi: 10.22458/urj.v10i1.2027 